Revista de la red interuniversitaria de estudios sobre las literaturas rioplatenses contemporáneas en Francia

$20 \mid 2019$

Situación

\title{
Desposesiones. La narrativa de Fernanda Trías
}

Dispossessions. The narrative of Fernanda Trías

Dépossesions. Les récits de Fernanda Trías

\section{Nora Domínguez}

\section{(2) OpenEdition}

\section{Journals}

Electronic version

URL: http://journals.openedition.org/lirico/8512

DOI: $10.4000 /$ lirico.8512

ISSN: 2262-8339

\section{Publisher}

Réseau interuniversitaire d'étude des littératures contemporaines du Río de la Plata

\section{Electronic reference}

Nora Domínguez, « Desposesiones. La narrativa de Fernanda Trías », Cuadernos LIRICO [En línea], 20 | 2019, Publicado el 01 julio 2019, consultado el 02 junio 2020. URL : http://journals.openedition.org/ lirico/8512 ; DOI : https://doi.org/10.4000/lirico.8512

This text was automatically generated on 2 June 2020

\section{(c) $($ ) $(9)$}

Cuadernos LIRICO está distribuido bajo una Licencia Creative Commons Atribución-NoComercialSinDerivar 4.0 Internacional. 


\title{
Desposesiones. La narrativa de Fernanda Trías
}

\author{
Dispossessions. The narrative of Fernanda Trías \\ Dépossesions. Les récits de Fernanda Trías
}

Nora Domínguez

1 En los libros de la escritora uruguaya Fernanda Trías (Montevideo, 1976) diferentes narradoras se plantan ante la ley, desdeñan sus fueros pero no dejan de rodearlos con enclaves paradojales entre sexualidad y literatura por donde circulan las distintas formas de la desposesión y el miedo. Desde la apuesta en Cuaderno para un solo ojo (2001) por el violento asesinato de la joven amante en el marco de una relación entre lesbianas al encierro familiar, la violencia del incesto y el infanticidio en La azotea (2001) ${ }^{1}$, donde se modula una versión arcaica y arriesgada sobre el sacrificio ejecutado por una madre, Trías va colocando vidas abandonadas que interpelan los límites de las instituciones y de sus normas para poner en entredicho los marcos de lectura e inteligibilidad de la violencia en sus diferentes versiones sociales, sexuales y estéticas. Su producción arroja sobre el campo de lo literario, sin duda activo y abierto a la experimentación, una perspectiva dedicada a responder ciertos interrogantes: qué tipo de voz construye una subjetividad que hace de la ciudad ajena un espacio en el que nunca abandonarse del todo (sobre todo en la mirada atormentada de la narradora uruguaya de "Bienes muebles" sobre Buenos Aires); cuáles son los costos que ese modo del estar urbano produce sobre las jóvenes migrantes latinoamericanas por causas económicas o culturales (especialmente en algunos de los relatos de No soñarás flores, 2017, y "Bienes muebles"2); cómo se configura un punto de obsesión narrativa que es al mismo tiempo una pregunta insistente sobre la sexualidad y los modos de ver en Cuaderno para un solo ojo, es posible echar raíces si las miradas se deslizan peligrosamente desde arriba, desde el encierro más absoluto ( $L a$ azotea) o desde la incertidumbre de los recorridos urbanos; cuáles son las condiciones de enunciación de esas voces siempre agónicas, situadas en el centro de diferentes desposesiones y disponibles para narrar las formas del miedo. 


\section{Hacer literatura con el miedo}

Yo, más asustada de él que de los peligros de la ciudad, subí a la terraza y casi consideré la posibilidad de saltar del techo. Pero no era eso, tampoco. "Miro esta cuchara y no sé si ese pensamiento es mío o es de él”, le dije una vez a Julia. El miedo se había convertido en mi odradek ("tengo miedo de mí mismo"); el miedo era esa costra negra que se acumula entre los azulejos del baño, era la mugre endurecida dentro de mí, mis propias articulaciones, de modo que no podía vivir sin él, pero anquilosada como estaba, tampoco podía moverme, (Trías 2013: 30)

2 Esta cita de "Bienes muebles" combina una escena actual, socialmente extendida y visibilizada por la cultura mediática y denunciada por el activismo feminista, el miedo de una mujer a la violencia ejercida por su pareja, con una referencia literaria de evocaciones diversas. Kafka comienza la serie con la creación de la figura del odradek que aparece en su texto "Preocupaciones de un padre de familia" (La condena, 1919). Otros lo retoman: Borges en El libro de los seres imaginarios, Vila-Matas en la Historia abreviada de la literatura portátil, nombran a los odradek con relatos ambiguos y enigmáticos. El odradek es una criatura imaginaria, fantasmal, amenazante. Habitante de pasillos y escaleras, difícil de atrapar porque anda envuelta en hilos anudados de diferentes colores, Vila-Matas le inventa una tradición más amplia: Duchamp, Benjamin, Gombrowizc, Pessoa, Dalí que son su ejército de shandy. (1985: 55-64). La ciudad de Praga parece un espacio afín para estos carretes que pueden asociarse con un inquilino negro no exactamente humano, que asusta a sus huéspedes o víctimas y vive entre ellos enredándolos o adopta la forma del doble y los sobrevive. Por esta razón también puede provocar que los escritores abandonen sus viviendas porque los invade un poderoso miedo de sí mismos.

"Bienes muebles" se publica primero en forma de crónica y luego de manera autónoma como novela bajo el título La ciudad invencible. Retoma ese juego de referencias, nombra varias veces al odradek a lo largo de sus páginas, hace de él una figura familiar que en principio le sirve a la narradora para dar cuenta de su miedo y de una duplicidad siniestra ("el pensamiento es mío o es de él", dice la narradora) y luego va enlazando con otros sentidos. Figura de consistencia incierta, sin cuerpo ni forma, inclasificable, se presenta en el texto como una cita y de esta manera se alude a una cadena literaria para encontrar allí su referencialidad. Previamente, la trama narrativa fue preparando el encuentro, marcando las pautas del terror y el nombre de su agente, La Rata. El texto comienza con una caminata de madrugada durante el final del cumpleaños de la narradora, una joven traductora y escritora uruguaya que busca instalarse en Buenos Aires y termina con su partida hacia Nueva York. La reunión con unos pocos amigos se dispersa por las calles de Palermo cuando los personajes regresan a sus casas. Ella vuelve con su amiga Julia y es testigo de una conversación ensordecedoramente repetitiva: Julia respondiéndole a los gritos al novio que su "celular murió". Luego comienza su propia historia en Buenos Aires marcada por "cuatro mudanzas, una separación, una muerte" (2013: 20) y en el fragmento más o menos extenso llamado "Techos" narra las diferentes peripecias de jóvenes latinoamericanas y pobres que buscan dónde vivir, trabajar y estudiar en Buenos Aires. El derrotero de estos personajes de un "cosmopolitismo limítrofe" (Aguilar 2015: 267) se despliega por pensiones de señoritas para estudiantes extranjeras "mayormente de Bolivia, Paraguay y Perú o chicas de provincia" que pueden ser rechazadas porque estrictamente no son estudiantes y combinan sus estudios sobre cine con trabajos de payaso en 
supermercados. A partir del segundo intento de aparición de La Rata por medio de frenéticos mensajes, cadenas de mails que la rastrean, llamados desaforados a los que van a alquilarle un cuarto, la narradora no puede dar con una vivienda: "La Rata era el eslabón perdido en casi todos mis intentos por conseguir casa en Buenos Aires: yo aún no tenía amigos, no conocía a nadie" (28). Se va a Montevideo para poner distancia y cuando regresa alquila un cuarto diminuto de exorbitante precio en el barrio de La Paternal. Allí vive una mujer de noventa y tres años, abandonada por su hija durante todo el día, que "aúlla". La narradora no la auxilia y esta situación la enfrenta con su culpa y su propio terror: "Por entonces yo vivía con miedo" (29), dice y narra por primera vez su relación con La Rata, sus modos de amedrentarla y asustarla, su secuestro "por amor", el acoso al que la somete. La anciana en estado de indefensión es el objeto de violencia de una hija que dice no quererla, que le advierte que no se preocupe por su madre, alguien que "por dentro es otra cosa". Las marcas de la venganza y la vergüenza se advierten en el baño, en la costra negra de los azulejos, en la mugre, causa y efecto de esa cruel precariedad, miedo y venganza, tormento del otro y terror del yo. En ese marco surge por primera vez la referencia al odradek, criatura de la que la narradora no puede liberarse ni desprenderse ya que su presencia y el miedo que desata la captura e invade. Pero, en tanto irrupción textual, actúa como protección literaria.

"Bienes muebles" va diseñando recorridos urbanos en los que predominan las perspectivas desde arriba ("pasaba la mayor parte del tiempo en la terraza", "Igual que en la casa de La Paternal pasaba las tardes en la terraza", "Ahí agarré la costumbre de mirar techos, de acceder a las vidas ajenas a través de las pistas que dejaban en sus azoteas...) (74 y 32). Terrazas y balcones desatan en ella una imaginación desde donde descubrir vidas ajenas y calibrar perspectivas $\mathrm{y}$, si bien la primera vez que ese mirar desde arriba la lleva a considerar la posibilidad de saltar desde el techo (como señala el epígrafe de esta sub-parte), inmediatamente irrumpe la imagen del odradek como ese miedo interior que resulta la figura amenazante, porque es una figura de lo bajo, y paradojalmente tranquilizadora, en tanto salida a la literatura. La criatura entonces revierte el imaginario acto suicida que se deposita en el cuerpo, en las articulaciones como un miedo inaudito: no es solo el miedo a la violencia del otro sino el cotejo de descubrir la misma versión dentro de sí misma. Por eso el odradek, es el otro y mi propio yo, mi doble y mis vecinos literarios.

5 Para Benjamin el odradek es una extraña madeja o carretel parlante que nadie sabe qué es, un olvidado porque irrumpe en el mundo de lo cotidiano con la fuerza de lo arcaico. Para Adorno que rechaza la lectura de Benjamin del odradek como una presencia arcaica es el reverso del mundo de las cosas, signo de la distorsión y un motivo de la trascendencia, de la confiscación de los límites y de la superación de la muerte. El odradek sobrevive como un prolegómeno que antecede al problema de la escritura. Para Judith Butler que relee a Benjamín y a Adorno, el odradek sobrevive porque aparece en una escena de interpelación que le da una voz (2009:90). Cito a Kafka:

- ¿Cómo te llamas? le pregunto.

-Odradek- me contesta.

¿Y dónde vives?

-Domicilio indeterminado- dice y se ríe ...

6 La narradora de "Bienes muebles" como el odradek o con él va en busca de domicilios indeterminados. Retengo entonces de estas lecturas: la presencia de lo arcaico, la permanencia en los límites y su vinculación con la escritura y sobretodo la remisión a 
un encuentro e interpelación entre un yo y otro. Trías parece haber captado o leído muchas de estas notas literarias, filosóficas, afectivas, pulsionales que rodean a esta criatura y allí lo coloca como una presencia menor, casi inconsistente que emerge en el texto para decir algo. Si el odradek puede ser la figura de la culpa, de la humillación de sentirse víctima, del terror de convertirse en victimario, de la alienación y la supervivencia, su permanencia además subraya la precariedad y la fuerza de la violencia. No hay odradek sin marcos de violencia, su emergencia acompaña y dispara una interpelación a la ley y una demanda al estado, que pasa también, como en Kafka, por una excursión textual por la burocracia. Esta es la historia que se cuenta en "Bienes muebles", donde el miedo a sí misma que encarna la criatura fantasmal está contenida en un relato de subjetivación narrativa y de singularización literaria. Esos marcos de violencia se especifican en el texto de manera particular: constituyen una violencia hacia la mujer como categoría, como sujeto categorizable en términos de Rita Segato, una violencia sexual que incluye el acoso, la persecución, la intención de marcar, apropiarse y dominar del cuerpo femenino; es decir acciones asociadas a un régimen patriarcal que requiere de una violencia fundante sostenida en la superioridad masculina y en su necesidad de inscribir soberanía mientras persigue el aniquilamiento de los otros y de su condición de alteridad (Segato 2006 y 2013).

En la crónica de Trías el marco de inteligibilidad de la violencia nombra instituciones policiales, oficinas de salud mental y seguimiento psicológico y una red de amigos que "resguardan" la vulnerabilidad del cuerpo de la narradora que sostiene y hace valer una identidad jurídico-política y un sustrato personal de ciudadana extranjera ${ }^{3}$. Hay una vulnerabilidad contundente del sujeto por el ataque ya ocurrido y el terror de uno próximo, que convierte a la mujer en una desconocida para sí misma. Pero además hay una precariedad vinculada a la desposesión de los medios básicos de vida que parecen escasos o disminuidos frente a una implícita normalización social que quiere tener a los sujetos vigilados: la narradora es extranjera, tiene pocos amigos, está gestionando documentos, no tiene trabajo estable. Si en el enfrentamiento con La Rata hay expresión de un poder que se quiere soberano sobre el cuerpo femenino para constituirlo en víctima y usar su cuerpo como tributo, en la crónica la enunciación de la voz no está emplazada desde la víctima. Corrida de ese lugar, la primera persona decide disputar, desnudar y someter su verdad o la verdad de su cuerpo marcado por los golpes en las instituciones disponibles. La mujer despliega diferentes grados de autonomía: viaja sola, busca trabajo, elige pensiones o departamentos, construye un círculo de afectos, entabla relaciones con vecinas extranjeras, tiene amantes varones o mujeres, recorre la ciudad, sopesa sus diferencias sociales y lingüísticas, descubre barrios y a los personajes marginales que sientan su territorio en la calle. No solo es un sujeto autónomo sino un sujeto que resiste las normas sociales, una mujer que atiende a sus deseos (de sexo, de droga, de alcohol, de literatura), datos que la vuelven más vulnerable y culpable al entramado misógino. En los resquicios de los recorridos urbanos el miedo se nombra varias veces como una capa de suciedad que se deposita en los huesos. Como quien narra no es una víctima, la trama debe forjar una salida para la supervivencia. Será la misma esfera de la justicia, la que le posibilitará una de las salidas y es la literatura la que dará los marcos de referencia para circular de una a otra dimensión. Entre ambas, el miedo que endurece la piel, ofrece nombres y pasajes; del odradek de Kafka el texto pasa hacia otra cita literaria: los cadáveres de Perlongher. 
Son fundamentalmente tres los fragmentos que narran estas peripecias judiciales: "Techos", "Ronda nocturna" y "Círculos". En el resto, la historia de ninguna manera se abandona pero hay una fuerza narrativa, un deseo de continuar con el relato del descubrimiento de la ciudad que puja contra el guión que impone el relato de la violencia y de la denuncia y que la prosa sin duda no puede eludir y decide y logra transmitir. Volvamos al texto que va a narrar cómo la demanda de escritura se convierte en exigencia de ley. Mientras La Rata la cerca, la persigue, invade y busca someterla la conduce a una escena de montaje y pedido de justicia. Tomaremos una cita extensa, el texto dice:

Quería hablar únicamente de Buenos Aires, no mencionar el juicio y el hecho, entre absurdo y surrealista, de que en mi heladera estuvieran pegados los teléfonos celulares de los patrulleros que hacían ronda por el barrio. Pero no pude evitarlo, y tal vez termine contando lo que ocurrió en mi casa una madrugada de Abril y que tuvo como consecuencia la denuncia anónima de un vecino [...]. Imposible evitarlo, digo, porque mi Buenos Aires también estuvo hecho de juzgados, un edificio lúgubre justo detrás de uno de los shoppings más caros de la ciudad, con pasillos interminables, solo interrumpidos por pequeñas ventanas de vidrio opaco que se abrían por un instante y volvían a bajar con un golpe seco, de guillotina. Uno intuía que detrás de esas cortinas se movían los burócratas como animalitos laboriosos, aunque tal vez la verdadera utilidad del vidrio opaco fuera ocultar el hecho de que nadie hacía nada, de que tiraban la moneda para decidir la suerte de este o aquél. [...]

Una vez vi a un policía escoltar a un hombre esposado; sus pies, aunque estuvieran sueltos, parecían arrastrar un grillete. Por esos corredores yo también daba pasos cortos. En la fiscalía me dijeron "para que me quedara tranquila", que ya no podía hacer nada para detener esto, que el Estado (el Estado argentino, del que por entonces no tenía ni el documento) había intervenido de oficio y que yo solo podía optar entre colaborar o no. Mis odradeks estaban de fiesta; bailaban y escupían una baba que se endurecía en mis articulaciones.

Más sórdido que el Juzgado fue la visita a la Policía Técnica... (2013: 63-65).

Entre las oficinas de los peritajes psicológicos o en la de salud mental el personaje interpreta manchas de test de Rorschach o dibuja parejas disfuncionales. Frente a las disposiciones y aplicaciones que la ley impone y que ella va aplicando, finalmente el yo no logra reconocer un resguardo estatal para su miedo sino una recategorización judicial, una nueva victimización y se enfrenta a la contracara de un nuevo peligro. La colocación de los dos sujetos ante la ley: la narradora-víctima y el acosador-victimario objeto de una sanción legal, comparten esta vez, de manera implícita una nueva escena de interpelación. La letra de la ley la coloca ante la ley, los interpela a ambos de manera diferencial; el acoso tiene un nuevo episodio y sufre otra mutación. El abandono de la ciudad aparece como la posibilidad de la fuga que protegerá la vida, sobrevivir para continuar viviendo. Si en el cuento de Kafka el odradek pervive, superando el juego de la sucesión generacional y fiel a la lógica del fantasma, en la crónica de Trías el acto de fuga y de la búsqueda de una vida más allá de juzgados, expedientes y sentencias es producto de un renovado temor a la muerte, es resistencia y deseo de escapar. El movimiento no implica abandonar la precariedad sino despegarla de la victimización y aún más, rechazar los efectos de la ley, porque después de todo "el juicio no era mío, sino del Estado" (60). La burocracia, como en Kafka, en su estado de locura mayor, le dice a la víctima que no existe. Se inscribe así un espacio donde la apelación al estado en busca de protección resulta en la instalación de una nueva forma de violencia que implica una reconfiguración y aceptación de la precariedad (Butler 2010: 46-47). 
En el anteúltimo de los fragmentos, "Círculos", la historia se resuelve:

¿Por qué se habla de cerrar círculos o etapas como quien cierra un frasco de mermelada? Estamos abiertos; todo sigue abierto, en perpetuo riesgo de infección. Anoche mismo vi en internet la foto de un leopardo que desgarra el cuello de un antílope. El gesto del antílope, su entrega, la manera sensual en que arquea el cuello hacia atrás, ofreciéndose a la mordida fatal. El depredador asume, y eso también le reprocho a la Rata, que no quisiera pagar precio alguno. En su intento por desgarrarme el cuello hubo deseo, sí, pero un deseo vulgar, ignorante de que no hay muerte sin ofrenda ni sacrificio sin ritual.

Estábamos con Ricardo en su casa cuando recibí la noticia. Cada tanto nos sentábamos en el sofá con las manos en las rodillas y la mirada al frente, y escuchábamos Hay cadáveres en la grabación de Perlongher. La escuchábamos entera, sin hablar ni mirarnos, y después comíamos pizza con aceitunas. Supongo que ya habríamos terminado de cenar cuando abrí el correo en su computadora tan vieja que sonaba igual al pecho de un asmático- y encontré el mensaje. El primer mensaje de la Rata en cinco meses. Dudé en abrirlo. [...]

En su mensaje, la Rata aceptaba la propuesta de la fiscalía y se despedía diciendo: "Las mujeres son todas unas abusadoras protegidas por la justicia". Trabajo comunitario, terapia grupal, indemnización y no contactarme por ningún medio. Eso, durante un año. La constatación me llegó como una descarga eléctrica. Tanto tiempo esperando que el círculo se cerrara; ocho meses, casi, convencida de que la decisión del juzgado solucionaría todo, y ahora, por más favorables que fueran las condiciones, sentía cualquier cosa menos alivio. Archívese.

Más fácil para la fiscalía que para mí. ¿Cómo se archivan los expedientes internos? ¿Cómo se archivan los expedientes en ese lugar que también es un pasillo, largo y a veces oscuro, pero que no tiene ventanas de guillotina? "Se apilan", pensé, acumulan telarañas y polvo durante años y un día la pila no aguanta el peso y simplemente se nos viene encima." (2013: 108-110)

11 La burocracia es irracional, no se la puede alcanzar nunca pero nunca podemos desprendernos. En este momento del texto el odradek desapareció como figura mientras la Rata reaparece con su escritura en la pantalla, nombra la ley y sus "injusticias", o mejor su valencia diferencial o la asignación diferencial de la precariedad que la justicia aplica sobre unos y otras y así se impone (Butler 2010: 42). Ese otro es el grado cero del Semejante, el Semejante con el cual no se puede establecer ninguna relación porque es una Otredad monstruosa, propiamente inhumano, para decirlo en términos de Zizek (2010: 166-167). El odradek, que para Zizek, está fuera del tiempo y de la diferencia sexual (170) encuentra en el texto de Trías una de sus variantes en la Rata que cumple con el dictamen legal sin asumir su carácter de "depredador" mientras del otro lado (de la pantalla, de la ley) una mujer, la narradora, se escucha y se ve como cadáver. El odradek, pierde su consistencia fantasmática y se convierte en "rata"; la abyección dirige la torsión y esa materialidad adoptada hace de la diferencia sexual un movimiento productivo que realiza una regulación heteronormativa, va demostrando cómo interpela y circula por prácticas, discursos, instituciones y subjetividades para volver a confirmar la distribución desigual de la vulnerabilidad entre el orden masculino o femenino. El odradek, dentro de los cauces de los entramados que Trías dispone, reafirma la jerarquía de la valencia sexual sobre los cuerpos.

12 Esta es la torsión que realiza Trías con su cita del odradek, figura literaria de linaje masculino, moderno, refinado e ilustre. Lo trae a las arenas de la discusión por la diferencia sexual y reafirma sus signos de ambigüedad para situarlo en el centro de una discusión no saldada. Cómo se realiza la inscripción ante la ley y ante la literatura, es decir ante dos instituciones imposibles por las relaciones paradojales que ponen a 
funcionar todo el tiempo entre una diferencia sexual de la que no pueden dar cuenta o hacerse cargo plenamente y al mismo tiempo no hacen sino mostrar los intercambios e intervenciones que se dan en el juego violento entre los cuerpos marcados. Cada texto aporta una respuesta posible. El texto de Trías se define, determina o resuelve cuando lo real, el cadáver, aparece como cita (el poema de Perlongher), como voz grabada y como amenaza. Es el momento también, como ya dijimos, en que el personaje toma conciencia de una nueva situación de vulnerabilidad y actúa (Butler 2006: 55). En La azotea, la novela previa con la que la autora fue en principio reconocida en el mundo literario, el miedo no cabía en la forma menor y fantasmática del odradek. Instalado en el interior familiar, el miedo era un motor de desviación radical de lo familiar, la narración donde el descarte social de algunos cuerpos entonaba la melodía imposible y trágica de una buscada muerte grupal, como se verá en el apartado siguiente. Sin duda la recurrencia a la figura del odradek funciona no solo como una política de reescritura sino como una política afectiva y una experiencia que vuelve a contar el miedo, la envoltura que éste realiza sobre los cuerpos cuando no deja de aproximarlos y distanciarlos (Ahmed 2015: 105-132).

\section{“Tengo miedo de mí misma"}

13 El conjunto de las novelas y relatos de Trías marchan por diferentes territorios de la violencia, como ya se dijo, que punzan otros relatos sobre la ley. Las distintas ediciones asumen lógicas itinerantes tanto en sus formas de publicación como en los circuitos ficcionales que los personajes y narradoras asumen. Publicadas o escritas en Montevideo, Buenos Aires, Bogotá, España o Chile (La azotea, "Bienes muebles" o su retitulación La ciudad invencible o No soñarás flores, con varias ediciones en distintos países) proponen una perspectiva de la precariedad como marca de un régimen ineludible sobre los cuerpos (Lorey 2016) En este último volumen un cuento se destaca "N Astoria-Ditmars" que pone en escena otro estado de la desposesión, afirmado nuevamente en las marcas de la precariedad, como régimen económico-político que afecta los cuerpos, su dimensión social y afectiva, su modo de estar y actuar en el mundo del trabajo. Las formas de precarización laboral relativas a mujeres "extranjeras", una exiliada uruguaya que trabaja muchas horas en un bar en Nueva York y vuelve en el último subte a su casa, se sitúan en desplazamientos geográficos acotados, demarcados a través de movimientos mínimos y habituales y emplazados en miradas y puntos de vista laterales que advierten sobre esos ritmos extenuantes del trabajo excesivo. La suciedad, la muerte, un acostumbramiento de la pérdida son marcas de sujetos marginalizados por el esfuerzo cotidiano del trabajar y por los ritmos narrativos, demorados y precisos, que adoptan las historias.

Hay imágenes que se reiteran en los textos de Fernanda Trías. Los cuerpos y miradas planean hacia arriba o desde arriba mientras repetidamente contienen su posible caída: las presencias urbanas de los aviones al comienzo de "Bienes muebles", su crónica sobre Buenos Aires, o las visitas a la terraza para el personaje de su novela La azotea, refugio atravesado por la inminencia del terror, son maneras de descubrir desde arriba las diversas formas del derrumbamiento, como "cuerpos dados vuelta" (2013: 97) que tantean y se preguntan desde la suspensión misma cuál es la índole de esa perspectiva, especialmente cuando ella se cruza con los contenidos del miedo. Hay un miedo visible, palpable, explícito en las vidas de las narradoras de estos textos que toma diversas 
resoluciones formales. Un miedo que, en Cuaderno para un solo ojo, su primera novela, se transforma en poder:

Me siento por encima del mundo, poderosa, gigante. Sostengo la baranda con ambas manos y respiro hondo tres veces con los ojos cerrados. Me veo saltando por voluntad propia y cayendo en un vacío sin fin. Primero a toda velocidad -el aire me hace presión contra el pecho- y luego deteniéndome, como si estuviera siendo suspendida en el aire por hilos irrompibles pero tremendamente elásticos. Mi cuerpo tiene una consistencia esponjosa, por donde se cuela el viento. No hay carne ni huesos. El aire me limpia, me sana (2001: 62-63).

15 Esas miradas desde arriba simulan ser potentes pero resultan "huérfanas", desgarradas e impiadosas. En los mundos de abajo que le corresponde a cada novela, los cuerpos amantes y desesperados de los personajes se reconocen, se tocan para probar el erotismo, el amor o el espanto. En La azotea se narran las vicisitudes de un autoencierro en un departamento con escasa luz, desde el que se ve el paredón de una iglesia a través del cual Clara busca la perfección de la endogamia, el cerrojo de un círculo familiar en el que ella dispone de los cuerpos de su padre y de su hija, Flor, recién nacida de la unión con él. La niña nace y crece, en ese espacio identificando entre carcajadas, juegos y abrazos al padre y a la madre. Soberana en sus decisiones, la narradora retiene al padre, le impide salir de su dormitorio y lo conduce a la escena incestuosa. Así va construyendo un aislamiento progresivo en el que la falta de agua, de insumos domésticos, de dinero, junto al deterioro físico del hombre van situando los pasos de una situación que originalmente no le dejó elección al personaje y se fue convirtiendo en una acción imperturbable y trágica ("salir me gustaba cada vez menos" , "no me gustaba la gente extraña a mi familia", "estamos enterrados vivos") (2010: 71, 84 y 90). Aterrada pero decidida, la joven cumple con el programa. La novela se narra construyendo un tiempo presente pavoroso, circular, que retoma el pasado reciente como causa y proceso y exhibe la inminencia del drama en cada página sin que, como lectores sepamos a ciencia cierta cómo va a producirse la destrucción última. La escena de la niña muriendo en el texto en manos de una joven Medea, convencida y desquiciada, es el punto donde un relato sobre la desesperación se vuelve imagen del horror y del alivio. En esa vacilación trabaja la prosa, entre el progresivo deterioro y suciedad de la casa y de los cuerpos y un exterior del edificio en el que resuenan voces de vecinas no menos perturbadas, entre el silencio de un presente donde ya el destino familiar fue decidido y cuya agonía se relata y los ruidos amenazantes e inciertos de quienes vendrán a buscarla. El ritmo de la prosa oscila y pende, se detiene en el relato de la pesadilla o se abre hacia el goce y la auto-satisfacción de un orgasmo, registra la progresiva destrucción de la casa o se expande con el aire y la luz de la terraza. Va del susurro al grito, del ardor por el salto al terror por la caída:

No sé cómo se me ocurrió subir a la azotea. Nunca antes había subido, a pesar de que toda la vida había visto esa puerta de metal [...] Esa primera tarde subí sin imaginar siquiera que la azotea se convertiría en algo tan importante. Mi lugar, mi guarida. [...] El pretil no tenía baranda. Me acerqué casi hasta el borde pero mantuve el cuerpo más atrás que la cabeza. Calculé los metros que me separaban de la vereda y sentí el impulso de saltar. Imaginé que saltaba y que caía intacta: imaginé que daba un salto larguísimo y que cruzaba hasta el techo de la iglesia. Tuve que alejarme del borde no por vértigo, sino por miedo a ese deseo ridículo que podía volverse incontrolable (2010: 72-73).

El cuerpito de la beba también se ve suspendido desde la ventana hacia el exterior:

Casi me dio un ataque cuando papá levantó a Flor en brazos y la asomó por la ventana. Ella se afirmó en el borde y sacó media cabeza afuera. Le dije que la sacara 
de ahí enseguida. Se lo dije en un susurro, para evitar que nos oyeran, pero con la intensidad de un grito (2010: 89)

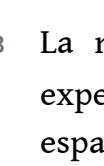
en el aire a la niña y señalando, dando a ver en ese cuerpo en alto y en el grito, el incesto que no se nombra, la convicción de que el juicio de "ellos", los de afuera, está latente al otro lado de la puerta; las lecturas de los matices de la luz sobre el paredón y sobre los cuerpos, la necesidad de la luz, los datos dispersos de un estado policial, las varias formas en que se expresa la abyección y el reconocimiento gradual pero severo de "que jamás habría un destino para nosotros" (118) son algunas de las modulaciones de esta novela que comienza y termina en el mismo recorte temporal. El ámbito de derrota y soledad, de miedo absoluto no es adicto al recuerdo. No se escribe para recordar sino para terminar con esa no vida. Fernanda Trías crea un espacio que remite al encierro de El cuarto mundo, la novela de Diamela Eltit de 1998, a quien reconoce como una de sus maestras junto a Mario Levrero (Murcia 2018) o al clima de enclaustramiento de algunos relatos de Indicios pánicos (1970) de Cristina Peri Rossi, escritos en los años previos a la dictadura militar uruguaya donde el desacomodamiento monstruoso de hijos y madres era producción inaudita de un estado de excepción en ciernes. Una vez desalojada toda ley familiar, la voz de la mujer, potente en su acto criminal y en su don para el relato, espera el juicio social y el cierre de la historia se vuelve explosión y cancelación del sentido. La novela de Trías encuentra varios recursos para dividir el tiempo aunque la
experiencia de los personajes insista en soslayarlo y en manifestar la opresión del En ese odio femenino se concentra no solo toda su posible criminalización sino una sospecha absoluta. Cuando esa furia solo se puede colocar en la queja femenina que se descifra como un vaciado del odio se soslaya lo que esa destrucción tiene de pérdida. Por eso la operación ideológica que la historia consolidó para las madres fue fructífera, en ese disparador del odio, que la tradición viril descubre en las madres, se justifica la desconfianza de las sociedades en el duelo de las mujeres (Loraux 1995: 99-100). Deformados ya estos sentidos en las formas de vida actuales, su reaparición en algunas ficciones renueva el carácter arcaico y disponible y, por lo tanto, inquietante, sobre las madres y sus deseos.

\section{Comunidades dañadas}

Los primeros pasos de la entrada en la literatura de Trías constituyen un reto, una iniciación desafiante en el terreno de la ficción que se decide por el sacrificio de una niña y el asesinato de una joven. ¿Cuál es el valor simbólico de estos asesinatos por mano de narradoras en primera persona, soberanas de sus actos y que cuida de su vida 
en La azotea o que se declara amante de la joven en Cuaderno para un solo ojo? Hay un exceso en esa madre que los vecinos, la ciudad y la literatura precisan controlar. Hay un deseo incestuoso invertido que la escritura pretende gestionar y exhibir narrativamente. El exceso se paga con la cancelación grupal de la vida del yo, de su padre-amante y de su hija, es el momento en que la literatura, en medio del desamparo absoluto, se hace acción discursiva. Hay que dejar encerrado ese pesar y el horror que produce en el interior de la casa y hacer que el relato encuentre en los movimientos de la lengua los límites formales para canalizar ese dolor y su exceso. El pasaje al acto todo lo distribuye y un nuevo orden narrativo alcanza su coherencia. En él, Clara, la madre incestuosa y asesina, rodeada de cadáveres, se ve a sí misma y se pierde en el espejo de la no diferenciación, en el centro de un miedo absoluto que ella actúa y refleja. La determinación de estos materiales no solo toma partido por la relectura de la tradición trágica sino por la presencia de sus fibras de sentido en la cultura actual. Arcaico pero siempre disponible, como señalamos antes, el odio, el duelo, el crimen una vez más se reorganizan.

Cuaderno para un solo ojo fue finalizada en 1998, el mismo año que Trías escribió La azotea. Ambas fueron publicadas en 2001 pero Cuaderno para un solo ojo fue su primera novela. Así lo informa la contratapa y la página de créditos de un librito de factura artesanal que es parte de una colección, hoy fuera de catálogo, dirigida por Mario Levrero. El escritor, fallecido en 2004, escribió en la página de créditos: "Los libros de esta serie inicial han sido todos elegidos por mí. Son auténticos escritores, de alma, no escriben "para" sino que escriben "por"; escriben por necesidad de escribir, que es la única fuente de la que surge auténtica literatura". Estas primeras novelas de Trías parecen escritas por desesperación. No hablo de un estado emocional de su autora sino de una violencia de la prosa, de su ritmo, de su transcurrir por la incertidumbre de ciertas zonas de la historia o el desgarro afectivo del personaje principal. El fluir textual se desliza y arrastra con precisión y maestría, sitúa los puntos y las notas afectivas y desesperadas hacia un clímax que se resuelve como una urgencia provocadora de la sexualidad que otra vez atenta contra la ley. En esta resolución hay dos rasgos que me interesa marcar. Por un lado, la historia se narra como una historia desgarrada de amor entre mujeres: Diana, casi una niña y Fabiana, la narradora que vira sin declararlo del todo hacia un posible Fabián, de origen e identidad incierta. Su tránsito, ambiguo, confuso de una a otro se sube a unos celos incontrolables que terminan en asesinato. Esas formas de persecución, apropiación y aniquilación de Diana se saturan con todas las notas de una identidad viril que sin embargo se sostiene durante todo el relato en una enunciación femenina. El amor entre lesbianas declina hacia una transformación que no afecta solo la trama sino las notas corporales que van conjugando la identidad posible y dolorosa de un sujeto trans. Quien mata de esta manera a una joven amante, inscribiendo su absoluta propiedad sobre ella, se hace varón, copia sus actos, remeda sus nefastas poses. El detenimiento en las puñaladas, en la descripción del cuerpo ensangrentado están muy lejos de presentarse como el texto inicial de alguien que escribe su primera ficción. Trías revelaba en esa primera nouvelle, escrita bajo el título de un cuaderno, cómo la pasión y la violencia de los cuerpos y de la escritura eran parte de una perspectiva doble, desviada, maldita, "producto de un solo ojo huérfano" (87). Este ojo de la psicoanalista que se desprende y rebota solo en varias escenas es el objeto siniestro que, como el pájaro en La azotea, actúa como una anticipación abyecta de la aparición más literaria del odradek en el texto que les sigue a estas dos primeras novelas. 
22 Ya se señaló cómo en "Bienes muebles" la ciudad, aunque extranjera, se abre a la crónica y a sus necesarios recorridos y paisajes, se mezcla con los objetos que están a la venta; los cuerpos intercalan contactos, descubrimientos, formas de combatir las múltiples precariedades. Se camina, se observa desde arriba, se conversa, se trabaja y se vive. En lugar del agobio del encierro: los ruidos, los aviones, los viajes en colectivo, las referencias literarias, las vecinas extranjeras, los personajes que viven en la calle y esa figura pequeña, menor, que se hace presente para arrastrar una genealogía literaria, el odradek. Contemplado en este punto de llegada, a la luz de las primeras ficciones de la escritora, la criatura fantasmal parece asumir otras protecciones y expectativas que se afanan en encontrarle nuevas modulaciones al miedo y otras políticas de escritura. Los personajes femeninos, dañados, renuncian a pasar al acto pero prueban con las imperfectas salidas por los pasillos de la ley. No podemos sino recordar que se trata de una primera persona afincada en las dotes "realistas" de la crónica como género no ficcional y, por lo tanto, en las alianzas que ella entabla con la autobiografía.

Antes de resolverse por la huida de su protagonista, "Bienes muebles" diseminó otras referencias literarias también anudadas a cuerpos de mujeres y a su condición precaria. Si la presencia de Borges es un epígrafe sobre la ciudad y una reflexión de las huellas de la ciudad sobre la literatura argentina y su relación con la uruguaya; también es el infierno de Swedenborg, "ese infierno de vida del necio que ni siquiera se sabe necio" (2013: 60-61). Las referencias veladas se continúan en esta línea: el cuento de Flannery O'Connor sobre el vendedor de biblias que seduce a una mujer para robarle una pata de palo ("La buena gente de campo") o la aparición de un personaje que se llama Delmira. Se trata de la futura compañera boliviana de la narradora que descubre en la primera pensión y cuyo nombre recuerda inevitablemente a la poeta Delmira Agustini, asesinada por su exmarido en un hotel. Hay otra uruguaya, Graciela, a quien la narradora se refiere cuando vuelve al barrio por primera vez después de la denuncia y distingue las esquinas, los basurales, el colchón del viejo que duerme en la calle y a su compatriota que hace cuarenta años que vive ahí. Una mujer que lee libros y revistas y a quien la calle enloqueció después de que la abandonara el marido. "A mí me resultaba difícil imaginar cómo alguien podía arruinar su vida por algo tan común como el fin de un amor" (78). Todas mujeres solas, marcadas por un abandono y una violencia. Pero hay un personaje importante cuya presencia atraviesa el texto con quien la narradora entabla una relación afectiva. Marita es una inmigrante puertorriqueña que está en Buenos Aires, viviendo con una sobrina. Su marido la abandonó en medio de una operación quirúrgica por la que perdió una pierna. Si Marita es otro personaje señalado por los efectos de la violencia de género, sus apariciones recorren el texto y la vida de la narradora en escenas luminosas de hospitalidad y compañerismo, de furtivas y secretas borracheras, de generosidad compartida y principalmente de conversaciones y miradas desde arriba, desde las ventanas y azoteas, en este caso como perspectivas liberadoras de encuentro emocional. Marita se vuelve a Puerto Rico, como ella se va a Nueva York; la despedida en los pasillos del edificio, con los objetos típicos de las casas de alquiler, las citas a dueños e inquilinos, las luces artificiales, techos y piernas falsas, las sonrisas sostenidas y abrazos cortos hacen de las dos extranjeras, "turista(s) en unas ruinas" (65), sometidas al desafío de bucear nuevamente por "territorios sin cartografiar". Es una de las percepciones fuertes del personaje que huye buscando vivir tranquila porque tiene miedo y Buenos Aires le resulta un estado policial y el cuerpo "un campo minado". Buenos Aires pasa a formar parte de la lista de ciudades en las que, como Puerto Rico, no se puede vivir (“No se puede vivir en un país así”, dice Marita) (59), y en 
donde hay que buscar otra forma de vida. Es el momento de la despedida de la ciudad, de la constatación de que "No hay territorio sin un vector de salida. Miré el reloj, eran casi las cuatro. "Me voy de Buenos Aires para quedarme" le dije a Baigorria antes del abrazo de despedida: canta el hotogisu/ precisamente hoy/ que no hay nadie" (113), este haiku japonés de 1690 condensa el movimiento hacia el aire. Si "la ciudad es otra cosa: una construcción hecha de personas, de afectos" (42), Marita y ella, dos extranjeras de "domicilio indeterminado" como se había representado el odradek kafkiano cuando habló, se protegen para construir una memoria compartida más allá del miedo. Una comunidad femenina que, aunque dañada, rasga el espacio narrativo con una versión afirmativa y hospitalaria de los lazos entre mujeres.

\section{BIBLIOGRAPHY}

Adorno Theodor, “Apuntes sobre Kafka”, Prismas. La crítica de la cultura y la sociedad, Barcelona, Ariel, 1962, p. 260-292.

Aguilar Gonzalo, “Oriente grado cero: Happy Together de Won-Kar Wai”, Más allá del pueblo. Imágenes, indicios y políticas del cine. Buenos Aires, FCE, 2015, p. 267-280.

Ahmed Sara, La política cultural de las emociones, México, UNAM, PUEG, 2015.

Benjamin Walter, “Construyendo la muralla china”, Iluminaciones, Madrid, Taurus, 1999, p. 209-217.

Butler Judith (2006), Vida precaria. El poder del duelo y la violencia, Buenos Aires, Paidós,

--- (2009), Dar cuenta de sí mismicioso. Violencia, ética y responsabilidad, Buenos Aires- Madrid, Amorrortu.

--- (2010), Marcos de guerra. Las vidas lloradas, Buenos Aires, Paidós.

Kafka, Franz. "La preocupación de un padre de familia”, Web. Consultado el 1/05/2019.

Loraux Nicole, Madres en duelo, Buenos Aires, Ediciones Equis, 1995.

Lorey Isabell, "Introducción”, Estado de inseguridad. Gobernar la precariedad, Madrid. Traficantes de sueños, 2016, p. 17-30

Murcia G. Vivian, "Fernanda Trías: "Ser una escritora mujer es un mero dato, no es ninguna afirmación sobre el tipo de escritura"”, El porta(l)voz. Relato iberoamericano, Ibe Tv, Web. Consultado el 30/11/18.

Segato Rita, (2013) La escritura en el cuerpo, Buenos Aires, Tinta Limón.

Segato, Rita, (2006) “¿Qué es un feminicidio?” en Mora Nro. 12, p. 21-32

Trías Fernanda, (2001) Cuaderno para un solo ojo, Montevideo. De los flexes terpines/05.

--- (2010), La azotea. Uruguay. Punto cero, 1ra. Edición 2001.

--- (2013), “Bienes muebles” en Trías, Fernanda y Andrés Barba, (des) aires, Santiago de Chile, Brutas editoras. 
--- (2015), La ciudad invencible. Montevideo, HUM.

--- (2017), No soñarás flores. Montevideo, HUM.

Vila-Matas Enrique, "Laberinto de Odradeks", Historia abreviada de la literatura portátil, Barcelona, Anagrama, 1985, p. 55-64.

Zizek Slavoj, Visión de paralaje, Buenos Aires, FCE, 2010.

\section{NOTES}

1. Esta novela fue reeditada en Caracas en el 2010, en Bogotá en el 2015 y en Madrid en 2018.

2. "Bienes muebles" se publicó en Brutas editoras, una editorial móvil que operaba en simultáneo desde Santiago de Chile y Nueva York que reunía relatos de viajeros, miradas extranjeras sobre una misma ciudad, a través de la reunión de firmas masculinas y femeninas. Más tarde se publicó como novela con el título La ciudad invencible (2015).

3. Por esos años en la Argentina se estaban discutiendo leyes de protección a la violencia sobre las mujeres y se iba gestando un incipiente manojo de leyes de las que las mujeres atacadas podían ir echando mano.

\section{ABSTRACTS}

The writer Fernanda Trias (Montevideo, 1976) places different feminine narrators before the law to question and surround it and in the same gesture criticize the paradoxical arrangements of sexuality and literature where various forms of dispossession and fear circulate. From the initial proposal of family confinement, women murder, the violence of incest and infanticide in the first novels to the re-elaboration of literary figures of fear Trías create abandoned and precarious lives who challenge the limits of institutions and their norms to question the reading and intelligibility frameworks of violence in its different social, sexual and aesthetic versions.

En la producción de la escritora Fernanda Trías (Montevideo, 1976) las diferentes narradoras se plantan ante la ley, desdeñan sus fueros pero no dejan de rodearlos para cuestionar los enclaves paradojales entre sexualidad y literatura por donde circulan las distintas formas de la desposesión y el miedo. Desde la apuesta en sus primeras novelas por el encierro familiar, el asesinato por celos y la ambigüedad sexual, la violencia del incesto y el infanticidio hasta las reelaboraciones de figuras de la tradición literaria sobre el miedo, Trías coloca vidas abandonadas que interpelan los límites de las instituciones y de sus normas para poner en entredicho los marcos de lectura e inteligibilidad de la violencia en sus diferentes versiones sociales, sexuales y estéticas.

Dans les récits de l'écrivaine Fernanda Trías (Montevideo, 1976), les narratrices font face à la loi et dédaignent leurs normes sans pour autant cesser de les évoquer afin de mettre en question les territoires paradoxaux qui associent littérature et sexualité, des territoires par où circulent de différentes formes de la dépossession et de la peur. Dès ses premiers romans, qui abordent l'enfermement familial, le meurtre des femmes, la violence de l'inceste ou l'infanticide, jusqu'à 
ses réélaborations de la tradition littéraire sur la peur, Trías met en question les cadres de lecture et d'intelligibilité de la violence dans ses différentes versions, sociale, sexuelle, esthétique.

INDEX

Keywords: Fernanda Trías, violence, sexuality, law, precariousness

Palabras claves: Fernanda Trías, violencia, sexualidad, ley, precariedad.

Mots-clés: Fernanda Trías, violence, sexualité, droit, précarité.

\section{AUTHOR}

\section{NORA DOMÍNGUEZ}

Universidad de Buenos Aires

noradominguezr@gmail.com 